\title{
Clinical potential of aclidinium bromide in chronic obstructive pulmonary disease
}

\author{
This article was published in the following Dove Press journal: \\ International Journal of COPD \\ 26 March 2015 \\ Number of times this article has been viewed
}

\section{Paul W Jones}

Institute for Infection and Immunity, Faculty of Respiratory Medicine, St George's, University of London, London, UK
Correspondence: Paul W Jones Institute for Infection and Immunity, Faculty of Respiratory Medicine, St George's, University of London, Cranmer Terrace, London SWI7 ORE, UK Tel +44208725 5372

Fax +44208725 5955

Email pjones@sgul.ac.uk
Abstract: Three long-acting muscarinic antagonists (LAMAs) are now available in Europe, providing clinicians and patients with a choice of interventions, which is important in COPD, which is clinically a heterogeneous disease. The first LAMA, tiotropium, has been widely used over the last decade as a once-daily maintenance therapy in stable COPD to improve patients' health-related quality of life and to reduce the risk of exacerbations. Administered via the HandiHaler ${ }^{\mathbb{B}}$ device, it is safe and well tolerated. Another new once-daily LAMA, glycopyrronium, has also been shown to improve health status and reduce exacerbations, and is well tolerated. The subject of this review is a third LAMA, aclidinium bromide, which was approved as a twice-daily maintenance bronchodilator treatment. In the pivotal Phase III clinical trials, patients receiving aclidinium achieved significantly greater improvements in lung function, reductions in breathlessness, and improvements in health status compared with placebo, for up to 24 weeks. In continuation studies, these improvements were sustained for up to 52 weeks. Pooled data showed exacerbation frequency was significantly reduced with aclidinium versus placebo. Preclinical and pharmacological studies demonstrating low systemic bioavailability and a low propensity to induce cardiac arrhythmias were translated into a favorable tolerability profile in the clinical trial program - the adverse event profile of aclidinium was similar to placebo, with a low incidence of anticholinergic and cardiac adverse events. While additional studies are needed to evaluate its full clinical potential, aclidinium is an important part of this recent expansion of LAMA therapeutic options, providing clinicians and patients with an effective and well-tolerated COPD treatment.

Keywords: aclidinium bromide, anticholinergic, long-acting muscarinic antagonist, chronic obstructive pulmonary disease, multidose dry powder inhaler

\section{Introduction}

Anticholinergic agents play a key role in COPD management, being recommended as a first choice, either as monotherapy or in combination with a long-acting $\beta 2$-agonist (LABA). ${ }^{1}$ For around a decade, only one long-acting muscarinic agonist (LAMA) tiotropium bromide - was available, but this picture changed in 2012, with the approval of two new LAMAs - aclidinium bromide and glycopyrronium bromide. All three LAMAs are noted as potential treatment options in the recent update from the Global initiative for chronic Obstructive Lung Disease (GOLD). ${ }^{2}$

\section{Tiotropium bromide}

Tiotropium has been widely used over the last decade as once-daily maintenance therapy in stable COPD. Currently, it can be delivered via the HandiHaler ${ }^{\circledR}$, a singledose dry powder inhaler, and the Respimat ${ }^{\circledR}$, a soft mist device which is a propellantfree, multidose inhaler. It has been extensively studied in patients with COPD - a recent Cochrane review identified 22 studies of good methodological quality that had enrolled 
23,309 participants with COPD. ${ }^{3}$ This review showed that tiotropium improved patients' health-related quality of life and reduced exacerbations and hospitalization. ${ }^{3}$

In the 4-year Understanding Potential Long-term Impacts on Function with Tiotropium (UPLIFT) trial using tiotropium via the HandiHaler ${ }^{\circledR}$ in moderate to severe COPD, improvements in forced expiratory volume in 1 second $\left(\mathrm{FEV}_{1}\right)$ compared with placebo were maintained throughout the trial (ranging from 87 to $103 \mathrm{~mL}$ pre-bronchodilator). The mean number of exacerbations was reduced by $14 \%$ and mean total St George's Respiratory Questionnaire (SGRQ) score was higher than with placebo at each time point throughout the 4 -year period by 2.3 to 3.3 units. However, the rate of decline in $\mathrm{FEV}_{1}$ - the primary outcome of the trial - was not significantly reduced by the use of tiotropium. ${ }^{4}$

In the UPLIFT trial, overall rates of serious cardiac adverse events (AEs) were all significantly lower in the tiotropium group than the placebo group (relative risk $[R R]=0.84$ ), although mortality was not significantly lower. ${ }^{4}$ Other publications have described conflicting observations regarding tiotropium and cardiovascular risk, ${ }^{3,5-9}$ including a new user cohort study in the UK, which identified a numerically (but not significantly) increased risk of stroke with tiotropium HandiHaler ${ }^{\circledR}$ versus LABA, but a significantly lower all-cause mortality (hazard ratio $[\mathrm{HR}]=0.70) .{ }^{6}$ In recent years, there has been increasing concern that tiotropium delivered via the Respimat ${ }^{\circledR}$ may have been associated with higher mortality, ${ }^{3,5-10}$ but the large, randomized Tiotropium Safety and Performance in Respimat ${ }^{\circledR}$ study (TioSPIR; NCT01126437), in which outcomes with tiotropium via Respimat $^{\circledR}\left(2.5\right.$ and $5 \mu \mathrm{g}$ doses) and HandiHaler ${ }^{\circledR}(18 \mu \mathrm{g})$ were compared in over 17,000 patients, showed no difference in all-cause mortality and no difference in efficacy as measured by exacerbation rate. ${ }^{11}$

\section{Glycopyrronium bromide}

Glycopyrronium bromide is a synthetic quaternary ammonium compound, which has been used for many years to reduce secretions and block cardiac vagal reflexes before surgery. ${ }^{12}$ Previously it was administered orally or as an injection, but a dry-powder formulation has now been developed, administered once daily (QD) via a single dose dry-powder device - the Breezhaler ${ }^{\circledR}$. Following promising results in early preclinical and clinical studies, ${ }^{13-16}$ a Phase III development program called GLycopyrronium bromide in COPD airWays (GLOW) was developed and has shown that glycopyrronium $50 \mu \mathrm{g}$ QD improved trough $\mathrm{FEV}_{1}$, breathlessness, and health status, ${ }^{17}$ and reduced exacerbations. ${ }^{18}$
In the GLOW 3 trial, glycopyrronium treatment was superior to placebo with respect to exercise endurance time after 3 weeks of treatment. ${ }^{19}$ The program also showed that it had an acceptable safety profile and low incidence of cardiac and anticholinergic AEs. ${ }^{17-19}$

\section{Aclidinium bromide}

Aclidinium bromide $400 \mu \mathrm{g}$ has been approved for the maintenance treatment of COPD. ${ }^{20,21}$ It has a twice-daily (BID) dosing regimen and is delivered by a multidose dry powder device named Genuair ${ }^{\circledR}$ in the EU and Pressair $^{\circledR}$ in the USA.

\section{Pharmacologic and pharmacokinetic profile}

Preclinical studies have shown that aclidinium displays high affinity for all five muscarinic receptors, with kinetic selectivity for $M_{3}$ receptors over $M_{2}$, and a shorter duration of action and a faster onset compared with tiotropium bromide. ${ }^{22}$ The drug's preclinical cardiac safety profile is also favorable. ${ }^{23}$

Pharmacokinetic studies in healthy volunteers showed that it is poorly absorbed into plasma and rapidly hydrolyzed into two major inactive metabolites, resulting in limited systemic exposure. ${ }^{24,25}$ Further studies in healthy individuals demonstrated that steady state was achieved within 2 days for aclidinium at all doses tested ${ }^{25}$ and that there was no effect on the QT interval at doses of up to $800 \mu \mathrm{g} \mathrm{BID} .{ }^{26}$ Renal impairment does not appear to increase systemic exposure to aclidinium, ${ }^{27}$ and its pharmacokinetic profile appears to be similar in younger (40-59 years of age) and more elderly ( $\geq 70$ years of age) patients with COPD. ${ }^{28}$

\section{Efficacy and safety}

Aclidinium has been extensively evaluated in patients with COPD (Table 1) $)^{29-39}$ and has also been the subject of a recent Cochrane systematic review. ${ }^{40}$ Early studies of aclidinium examined a QD schedule, ${ }^{37,38}$ but while in a dose of $200 \mu \mathrm{g}$ QD it significantly improved trough $\mathrm{FEV}_{1}$ in patients with COPD versus placebo, ${ }^{39}$ the improvement $(59-67 \mathrm{~mL}$ ) was below the suggested minimum clinically important difference (MCID) of $100 \mathrm{~mL},{ }^{41}$ although significant improvements in breathlessness and health status were seen and exacerbations were reduced. ${ }^{39}$

Subsequently, studies investigating higher doses and alternative dosing regimens were conducted, ${ }^{29,30}$ leading to two Phase III studies: the 12-week AClidinium in Chronic Obstructive Respiratory Disease I (ACCORD COPD I) study (Figure 1A) 31 and the 24-week Aclidinium To Treat Airway obstruction In COPD PatieNts (ATTAIN) study (Figure 1B) ${ }^{32}$ 


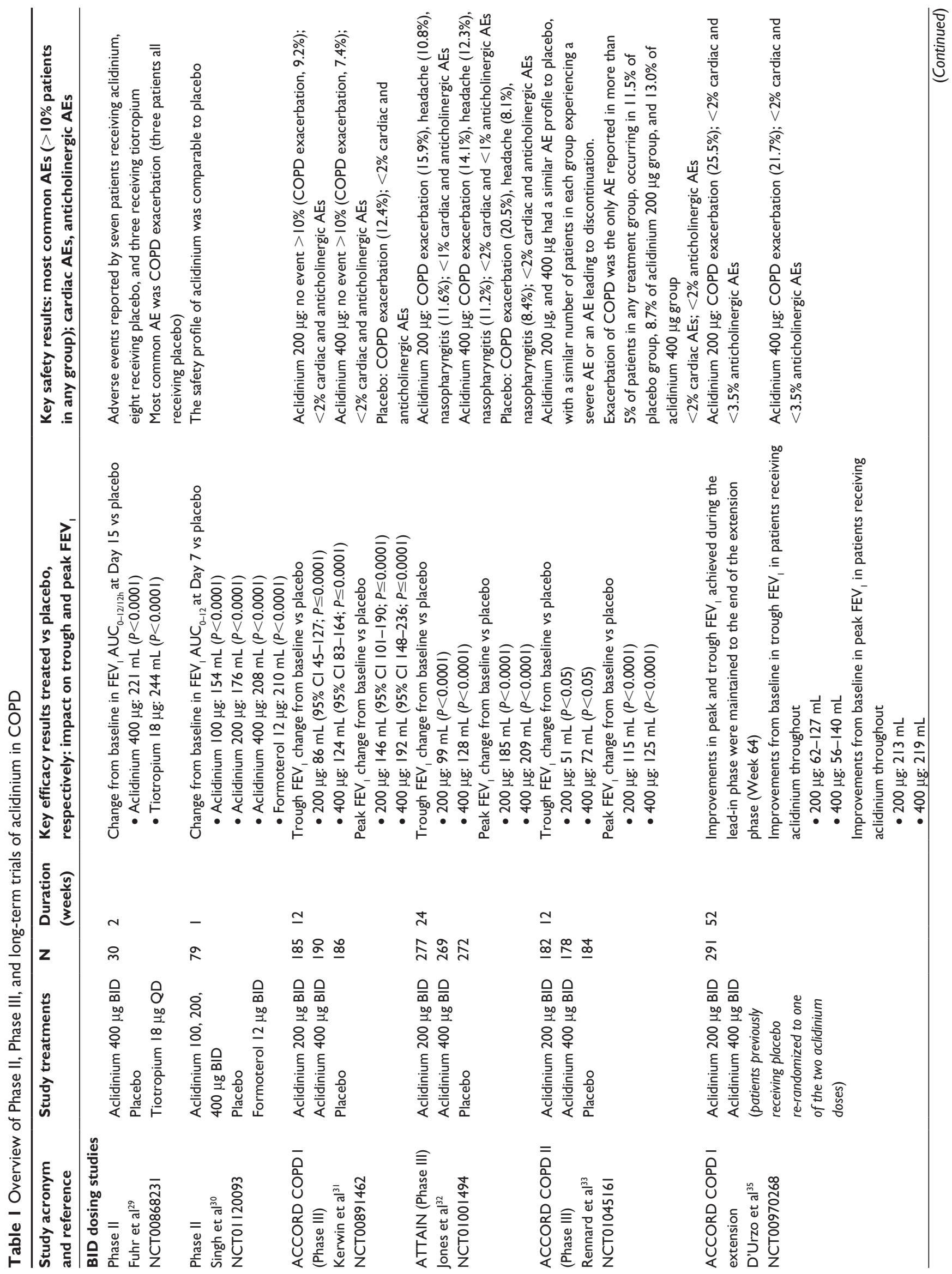




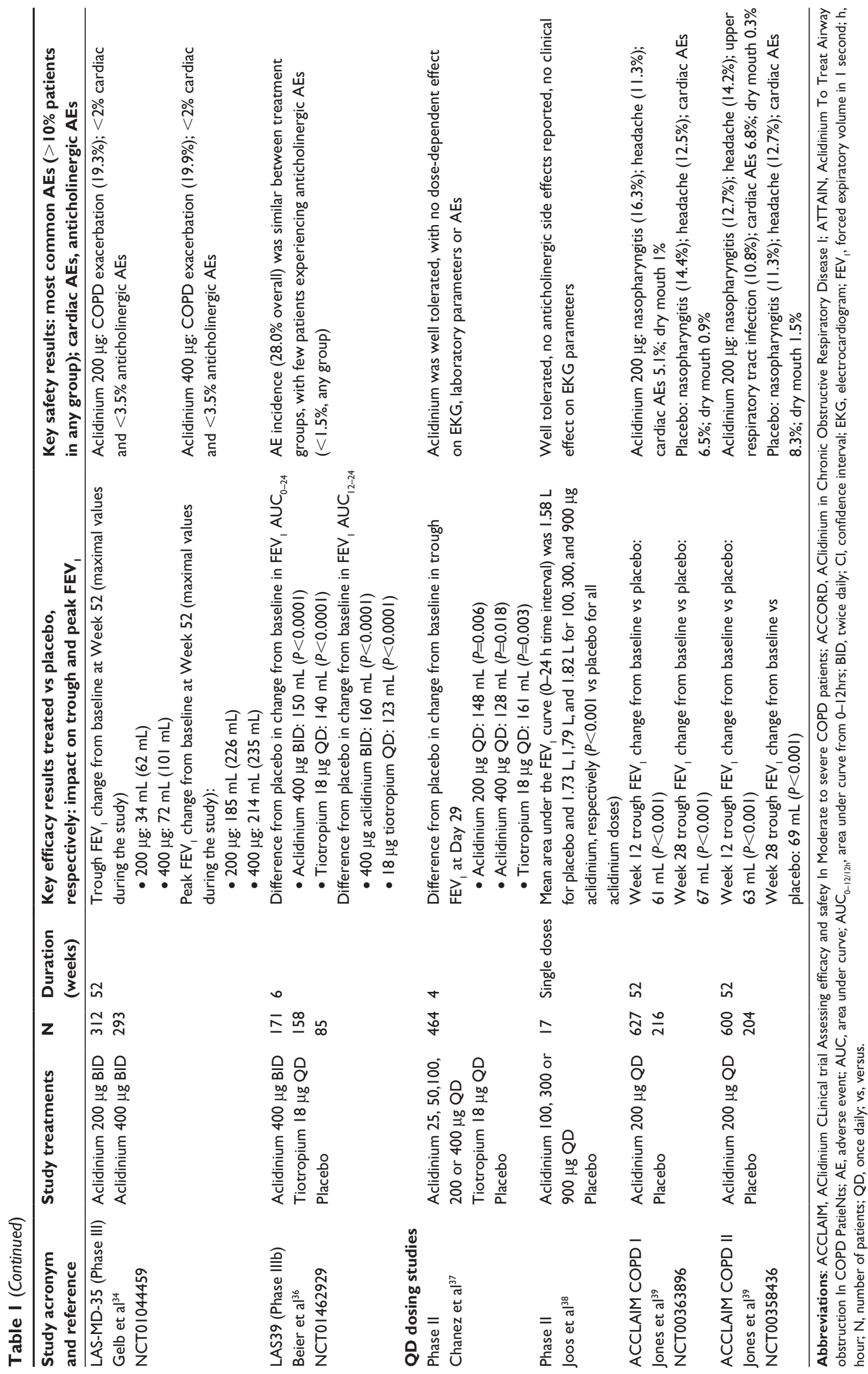


A

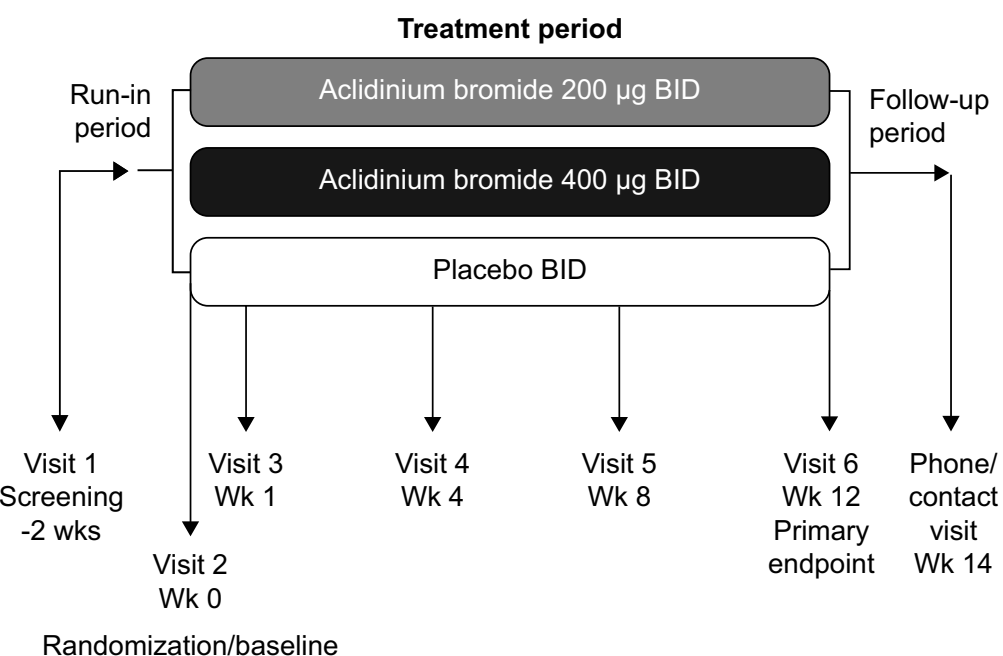

B

Treatment period

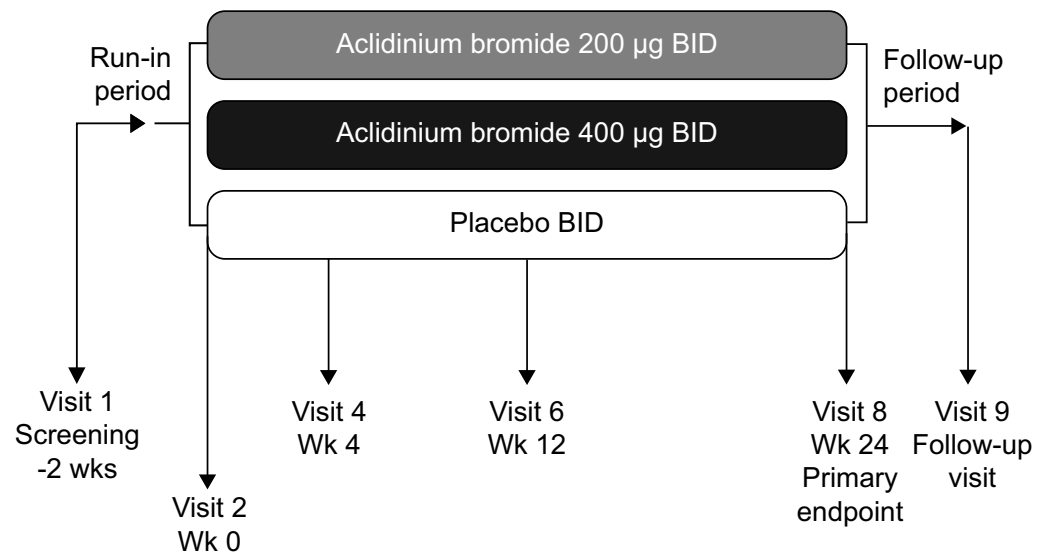

Randomization/baseline

Figure I Study designs for the two pivotal Phase III studies of aclidinium BID: (A) ACCORD COPD I, ${ }^{31}$ and (B) ATTAIN. ${ }^{32}$

Abbreviations: ACCORD, AClidinium in Chronic Obstructive Respiratory Disease I; ATTAIN, Aclidinium To Treat Airway obstruction In COPD PatieNts; BID, twice daily; Wk/wks, week/weeks.

These evaluated aclidinium at doses of 200 and $400 \mu \mathrm{g}$ BID versus placebo. Supportive studies include the 12-week ACCORD COPD II study ${ }^{33}$ and two long-term studies $^{34,35}$ (Table 1). Most recently, a 6-week Phase IIIb trial has compared aclidinium $400 \mu \mathrm{g}$ BID with placebo and tiotropium QD via the HandiHaler ${ }^{\circledR}$ in patients with stable, moderate to severe COPD. ${ }^{36}$

\section{Impact of aclidinium on lung function}

In the ACCORD COPD I study, the mean pre-bronchodilator $\mathrm{FEV}_{1}$ improved by $124 \mathrm{~mL}$ versus placebo (Figure 2A) and peak $\mathrm{FEV}_{1}$ by $192 \mathrm{~mL}$ versus placebo after 12 weeks (Figure 2B). The peak $\mathrm{FEV}_{1}$ achieved with aclidinium was significantly greater than for placebo from the first dose onwards $(P<0.0001){ }^{31}$ In the 24-week ATTAIN study, the results were very similar: mean improvement in pre-bronchodilator
$\mathrm{FEV}_{1}$ at Week 24 compared with placebo was $128 \mathrm{~mL}$ (Figure 3A), and mean improvement in peak $\mathrm{FEV}_{1}$ at Week 24 was $209 \mathrm{~mL}$. Again, these benefits were seen from the first dose until the end of the study (Figure 3B). ${ }^{32}$ The 12-week ACCORD COPD II study showed smaller improvements in trough $\mathrm{FEV}_{1}$, and this result is thought to be due to statistically significant imbalances between study arms in terms of baseline $\mathrm{FEV}_{1}$ and COPD severity. ${ }^{33}$ Two long-term studies have shown that improvements in $\mathrm{FEV}_{1}$ from baseline with aclidinium are sustained for up to 52 weeks. ${ }^{34,35}$ The Cochrane meta-analysis confirmed that aclidinium therapy resulted in statistically significant improvements in both trough and peak $\mathrm{FEV}_{1}$ compared with placebo. ${ }^{40}$

In a recently reported 6-week trial comparing aclidinium BID with placebo and tiotropium QD in patients with stable, moderate to severe COPD compared with placebo, 

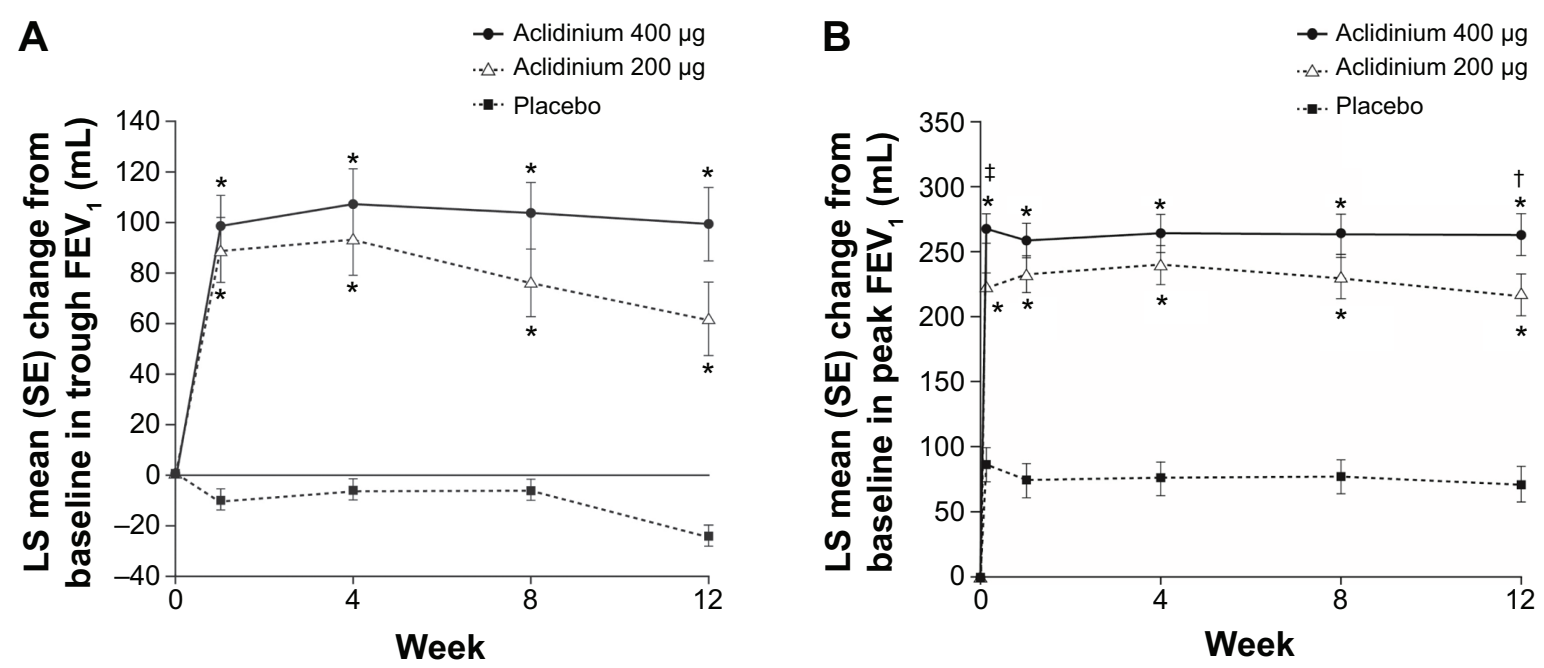

Figure 2 Change from baseline in (A) trough FEV, and (B) peak FEV, at Week 24 in ACCORD COPD I study.

Notes: $* P<0.00$ I vs placebo; ${ }^{\dagger} P<0.05$, ${ }^{\prime} P<0.01$ vs aclidinium $200 \mu$ g. From Kerwin EM, D’Urzo AD, Gelb AF, et al. COPD 20I2;9(2):90-I0I. Copyright $\odot 2012$, Informa Healthcare. Reproduced with permission of Informa Healthcare. ${ }^{31}$

Abbreviations: ACCORD, AClidinium in Chronic Obstructive Respiratory Disease I; FEV , forced expiratory volume in I second; LS, least squares; SE, standard error.

improvements in the area under the curve (AUC) over 24 hours were significantly greater with aclidinium $(156 \mathrm{~mL})$ than with tiotropium (117 mL, $P<0.05$ ). This difference was largely driven by a significantly greater improvement in overnight AUC with aclidinium (168 $\mathrm{mL})$ compared with tiotropium (100 $\mathrm{mL}, P<0.01)$, most likely arising due to the different pharmacokinetics associated with QD and BID dosing. ${ }^{36}$

\section{Breathlessness, health status, and COPD} symptoms with aclidinium

Significant improvements were seen in breathlessness, health status, and COPD symptoms in the pivotal trials. In both ACCORD COPD I and ATTAIN, by the end of the study, compared with placebo, the improvement in transition dyspnea index score reached the MCID. ${ }^{31,42,43}$ In ATTAIN at Week 24, the improvement over placebo in SGRQ score exceeded the MCID. ${ }^{42,44}$ In the two 52 -week studies, $45 \%$ of patients in LASMD-35 achieved a clinically significant improvement ( $\geq 4.0$-unit improvement from baseline) in SGRQ score at Week 52;34 similarly, in the ACCORD COPD I extension at 64 weeks, $64 \%$ of patients improved by more than this amount (Figure 4). ${ }^{35}$

The clinical study data synthesis presented in the Cochrane review demonstrated significant improvements in transition dyspnea index (eight trials, 4,490 patients) and SGRQ (seven trials, 4,420 patients) with aclidinium therapy compared with placebo. Furthermore, a higher proportion of
A

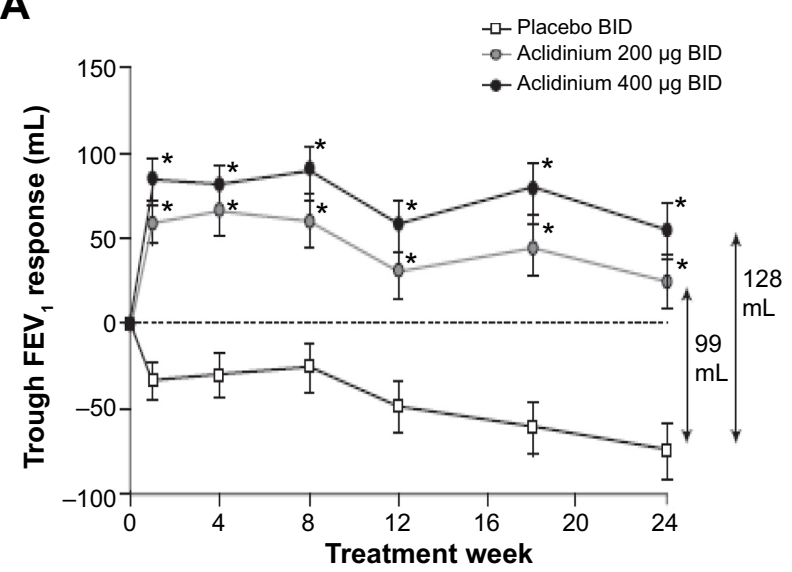

B

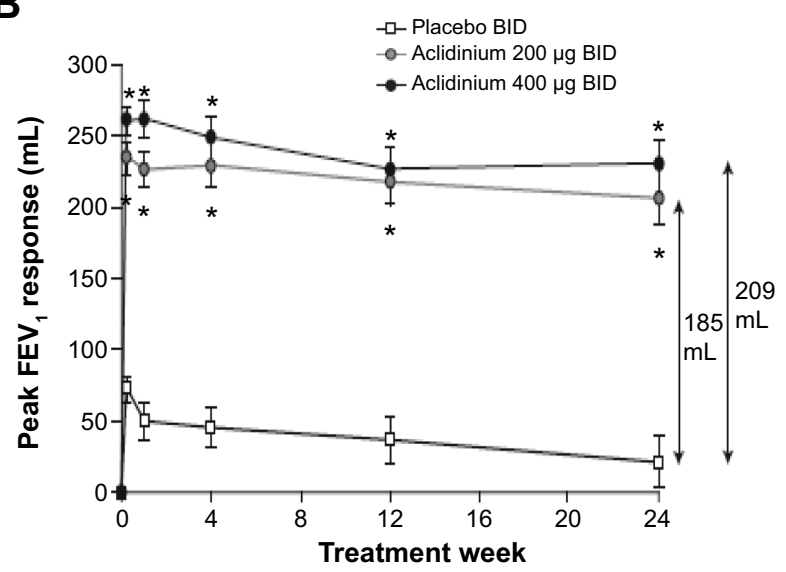

Figure 3 Change from baseline in (A) trough FEV, and (B) peak FEV, at Week 24 in ATTAIN study.

Notes: Data reported as least squares mean (standard error). $* P<0.000$ I for both treatments vs placebo. There were no statistically significant differences between the two aclidinium arms. Reproduced with permission of the European Respiratory Society: Eur Respir J, October 2012 40:830-836; published ahead of print March 22, 20I2, doi:10.1183/09031936.00225511.32

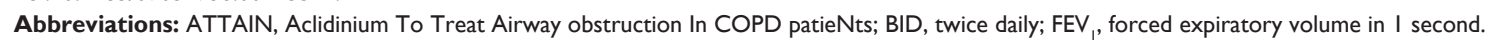




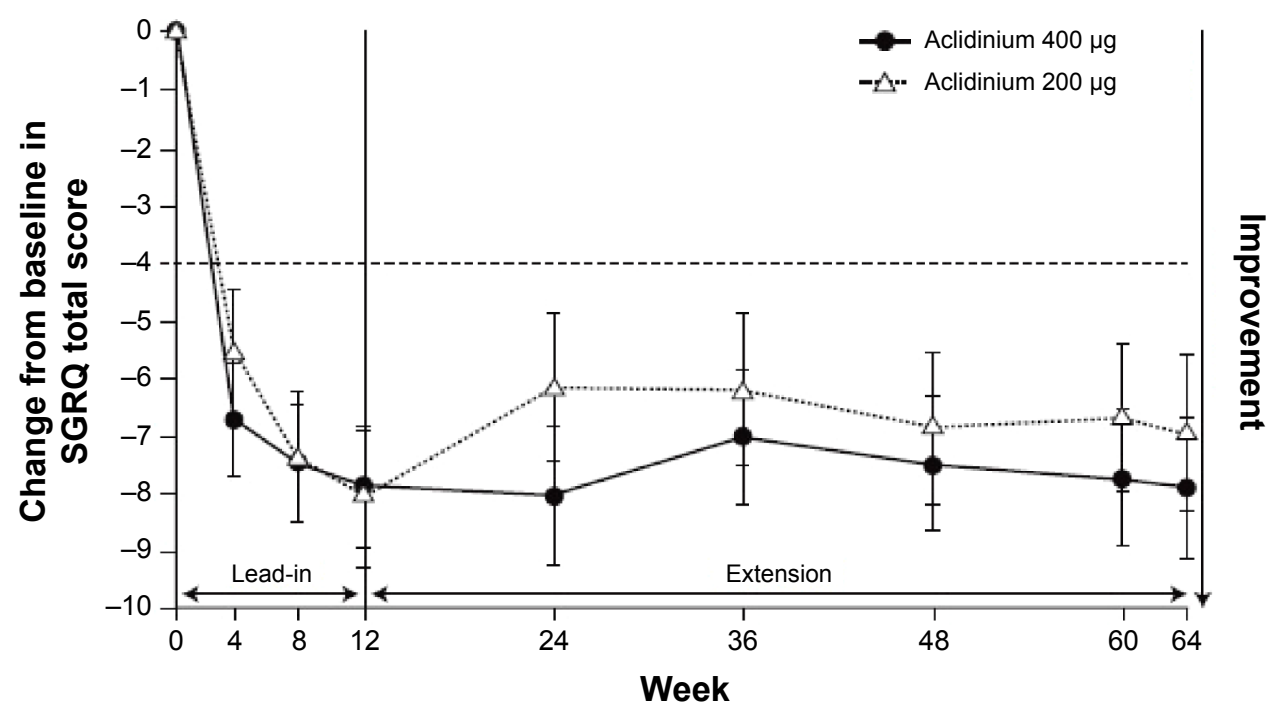

Figure 4 Least squares mean (standard error) change from baseline in SGRQ total score in patients on continuous aclidinium in I-year extension study of ACCORD COPD I. Note: From D'Urzo A, Kerwin E, Rennard S, He T, Garcia Gil E, Caracta C. COPD 20I3; 10(4):500-5I0. Copyright (C 20I3, Informa Healthcare. Reproduced with permission of Informa Healthcare. ${ }^{35}$

Abbreviations: ACCORD, AClidinium in Chronic Obstructive Respiratory Disease I; SGRQ, St George's Respiratory Questionnaire.

patients treated with aclidinium achieved the MCID in each of these measures, compared with placebo. ${ }^{40}$

In the ACCORD COPD I study, ${ }^{31}$ night-time and morning COPD symptoms were all significantly reduced among patients treated with aclidinium compared with those who received placebo (Figure 5), and the impact of breathlessness on early morning activities was also significantly reduced with aclidinium versus placebo (Figure 6). In the ATTAIN study, ${ }^{32}$ the EXAcerbations of Chronic pulmonary disease Tool-Respiratory Systems (EXACT-RS) daily diary was used as an exploratory outcome measure. This showed that aclidinium improved the total score and the component scores (breathlessness, chest symptoms, and cough and sputum) significantly more than placebo (Figure 7).

\section{Effect of aclidinium on COPD exacerbations}

The impact of aclidinium BID on COPD exacerbations was examined in pooled analyses of data from ACCORD COPD I and ATTAIN. ${ }^{45,46}$ Two methods were used to capture COPD exacerbations - health care resource utilization, in which an exacerbation was defined as an increase in symptoms on $\geq 2$ consecutive days requiring a change in treatment, and EXACT ${ }^{47}$ Pooled analyses of health care resource utilization assessments showed that aclidinium significantly reduced moderate to severe exacerbation rates by $29 \%$ compared with placebo. ${ }^{46}$ The synthesized data in the Cochrane review from ten aclidinium clinical studies in 5,624 patients found that the reduction in moderate exacerbations requiring treatment with systemic steroids

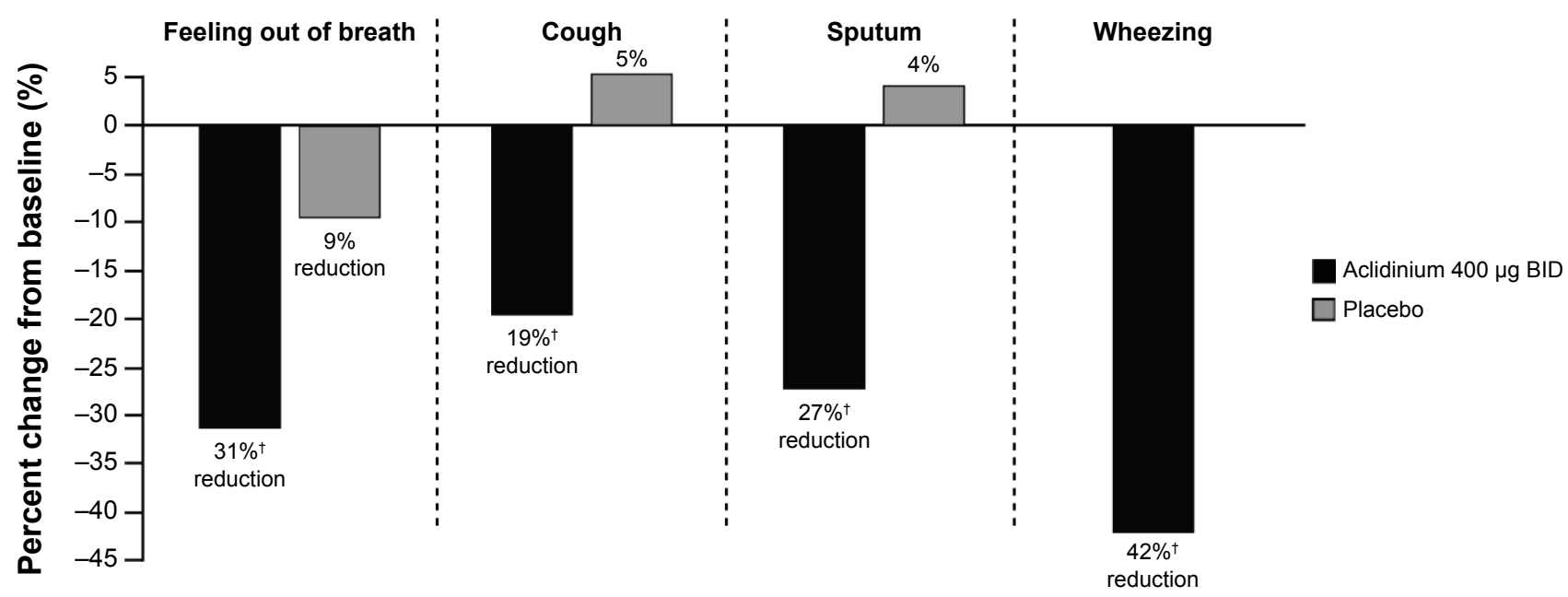

Figure 5 Percent change from baseline in frequency of night-time COPD symptoms at Week 12 in the ACCORD COPD I study

Note: ${ }^{\dagger} P \leq 0.0023$ vs placebo.

Abbreviations: ACCORD, AClidinium in Chronic Obstructive Respiratory Disease I; BID, twice daily. 


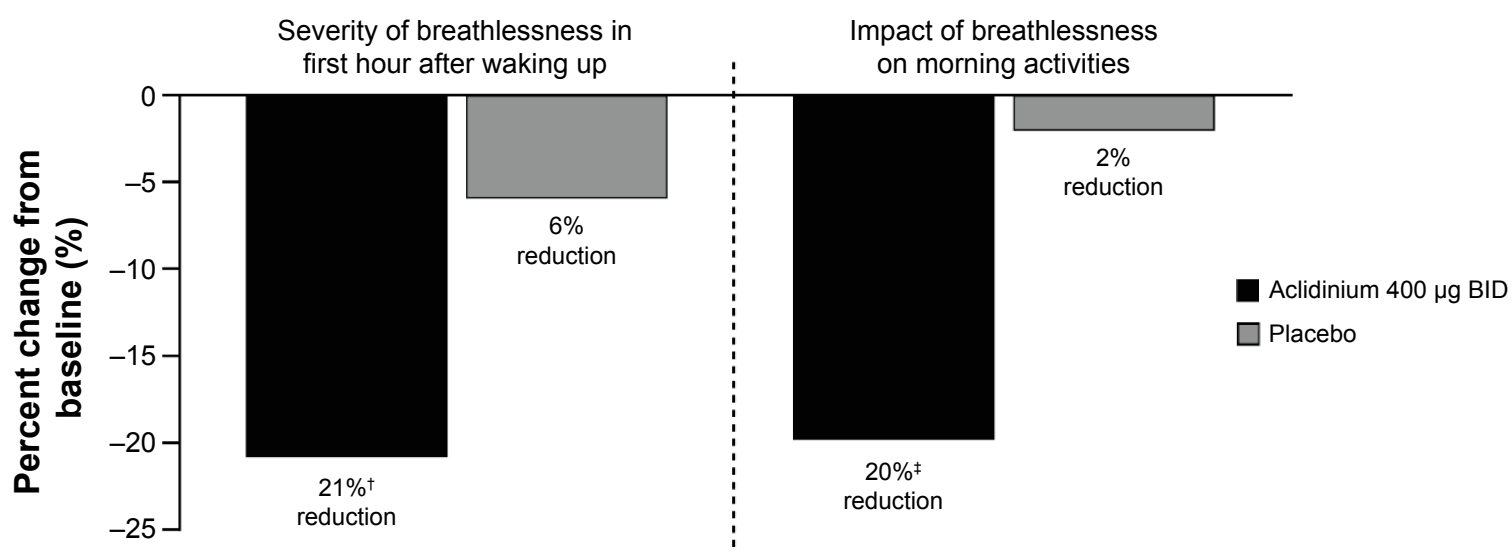

Figure 6 Percent change from baseline in severity and impact of early morning symptoms at Week I2 in the ACCORD COPD I study. Notes: ${ }^{\dagger} P=0.0009,{ }^{\ddagger} P=0.0002$

Abbreviations: ACCORD, AClidinium in Chronic Obstructive Respiratory Disease I; BID, twice daily.

and/or antibiotics did not reach significance for aclidinium versus placebo, but that aclidinium significantly reduced the frequency of exacerbations requiring hospitalization. ${ }^{40}$ However, it should be noted that these studies were not powered to investigate exacerbations, and the populations included were not enriched by recruiting patients with a history of frequent exacerbations.

\section{Inhaler preference}

In two randomized, double-blind, double-dummy, crossover studies ( $\mathrm{n}=109$ patients in total), more patients found the Genuair $^{\circledR}$ easier to use than Aerolizer ${ }^{\circledR}$ or HandiHaler ${ }^{\circledR}$ and reported that dose preparation with Genuair ${ }^{\circledR}$ was "very easy" compared with the other two inhalers $(65 \%$ vs $24 \%$

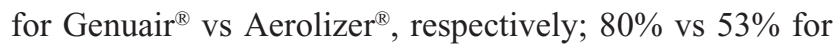
Genuair $^{\circledR}$ vs HandiHaler ${ }^{\circledR}$, respectively). ${ }^{48}$ Overall, more patients expressed a preference for Genuair ${ }^{\circledR}$ compared with
Aerolizer ${ }^{\circledR}$ or HandiHaler ${ }^{\circledR}{ }^{48}$ In a further study, significantly fewer patients made a critical error using Genuair ${ }^{\circledR}(10.5 \%)$ compared with HandiHaler ${ }^{\circledR}(26.7 \%){ }^{49}$

\section{Safety and tolerability of aclidinium}

In the Phase III and IIIb studies, aclidinium exhibited a good tolerability profile (Table 1 ). ${ }^{29-36}$ In the 12 -week ACCORD COPD I study, the overall incidence of AEs was very low and similar in aclidinium- and placebo-treated patients, with no evidence of a dose-harm relationship. In fact, COPD exacerbation was the only AE reported in $>5 \%$ of patients in any treatment group (placebo, 12.4\%; aclidinium $200 \mu \mathrm{g}, 9.2 \%$; aclidinium $400 \mu \mathrm{g}, 7.4 \%$ ). ${ }^{31}$ Other AEs were headache $(\leq 3.3 \%)$, nasopharyngitis $(\leq 2.6 \%)$, back pain $(\leq 2.7 \%)$, dyspnea $(\leq 2.6 \%)$, and arthralgia $(\leq 2.6 \%)$. A similar picture was observed in the ATTAIN trial, in which the most common AE was

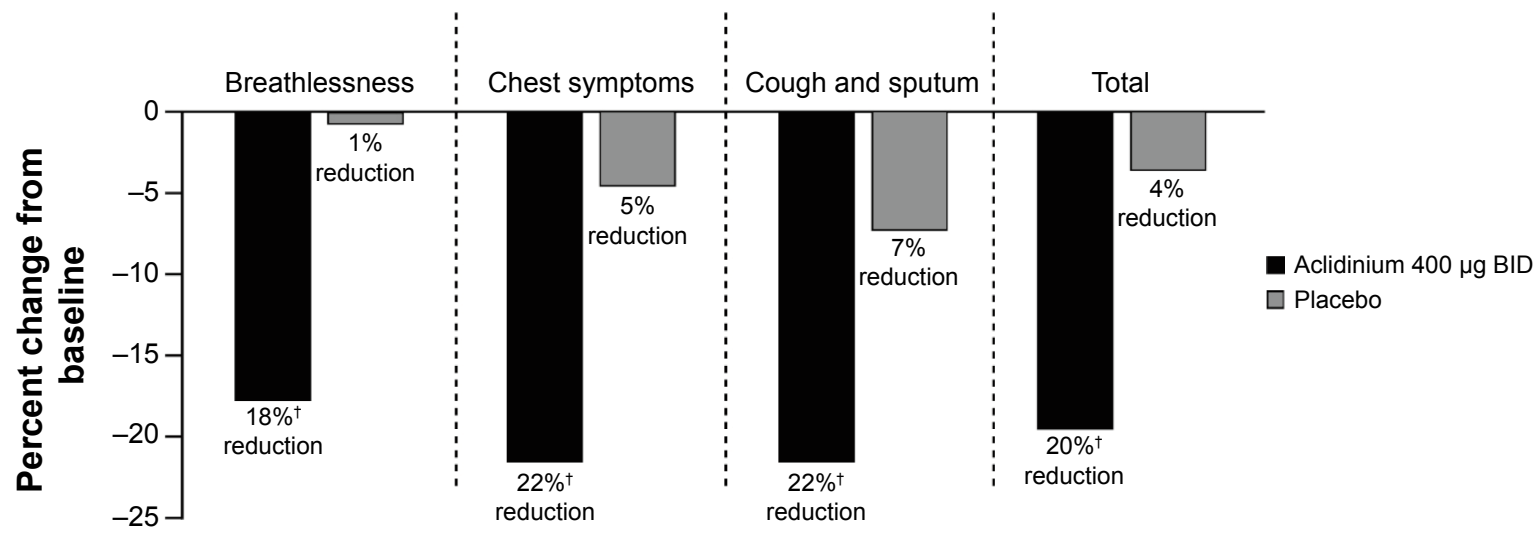

Figure 7 Percent change from baseline in daily COPD symptoms as measured by EXACT-RS scores at Week 24 in the ATTAIN study. Note: ${ }^{\dagger} P<0.000$ I vs placebo.

Abbreviations: ATTAIN, Aclidinium to Treat Airway Obstruction in COPD Patients; BID, twice daily; EXACT-RS, EXAcerbations of Chronic pulmonary disease ToolRespiratory Systems. 
COPD exacerbation (placebo, 20.5\%; aclidinium $200 \mu \mathrm{g}$, $15.9 \%$; aclidinium $400 \mu \mathrm{g}, 14.1 \%$ ), followed by headache $(\leq 12.3 \%)$, nasopharyngitis $(\leq 11.6 \%)$, back pain $(\leq 4.3 \%)$, and rhinitis $(\leq 3.3 \%) .{ }^{32}$ Cardiac AEs and anticholinergic AEs occurred in $<2 \%$ of patients in any treatment group in the two studies. ${ }^{31,32}$

The good safety and tolerability profile of aclidinium was confirmed in the longer-term studies, LAS-MD-35 and the ACCORD COPD I extension (Table 1). ${ }^{34,35}$ In particular, major adverse cardiac events in pooled data were low, with no evidence of dose dependency (1.6\% events with aclidinium $200 \mu \mathrm{g}$ BID and 1.4\% events with aclidinium $400 \mu \mathrm{g}$ BID). ${ }^{50}$ In the 6-week study comparing aclidinium with placebo and tiotropium, the incidence of AEs (28.0\% overall) was similar between treatment groups, with few patients experiencing anticholinergic AEs ( $<2.0 \%$, any group) ${ }^{36}$ Further confirmation of the tolerability of aclidinium is provided by the Cochrane meta-analysis, including ten trials and 5,651 patients, which found no significant difference in the occurrence of AEs between aclidinium and placebo. ${ }^{40}$

\section{Dose selection}

Several of the Phase II and III studies described in this review included two doses of aclidinium - $200 \mu \mathrm{g}$ and $400 \mu \mathrm{g}$ BID; however, the data have not revealed a clear dose-response relationship. The $400 \mu \mathrm{g}$ dose provides numerically greater improvements in most study endpoints compared with aclidinium 200 $\mu \mathrm{g}$, although there are exceptions, such as the improvements in SGRQ observed over 64 weeks (Figure 4). However, these studies were not designed to directly compare the two doses, and confidence intervals often overlapped. As there are no apparent differences in the safety profile of the two doses, and the 400 $\mu \mathrm{g}$ dose consistently provided the greatest improvements, this was the dose licensed by the EMA and FDA..$^{51,52}$

\section{Discussion}

As noted in the current GOLD guidelines, tiotropium, aclidinium, and glycopyrronium can all be considered as appropriate options for maintenance treatment in the stable COPD patient. ${ }^{2}$ This review concerned aclidinium in the context of two other LAMAs. What stands out as the difference between it and them, since they seem to have similar efficacy and safety profiles?

The low systemic bio-availability of aclidinium may be an advantage, but more data are needed, as this is a class of drugs with a generally low side-effect rate. The BID dosing does not appear to be a disadvantage compared to the QD regimes of tiotropium and glycopyrronium, since it may confer better overnight bronchodilation that may be particularly beneficial for patients with significant night and morning symptoms.

The three LAMAs also provide patients with a choice, as each is delivered by a different device, and some patients may prefer one over another. For example, the multidose Genuair $^{\circledR} /$ Pressair $^{\circledR}$ was preferred by more patients than the HandiHaler ${ }^{\circledR} .{ }^{48}$ More importantly, the critical error rate (errors of use that potentially result in poor lung deposition of the drug) was lower with the aclidinium device than the HandiHaler ${ }^{\circledR}{ }^{49}$ The device plays a crucially important role in determining the reliability of inhaled therapy, since poor technique is associated with increased health care resource use. ${ }^{53}$

In conclusion, when considering new inhaled drugs, it is important to look beyond the chemical entity and its pharmacology. Dosing regimens and inhaler performance may be equally important in determining relative advantages of one drug over another. That may be the case with aclidinium.

\section{Acknowledgments}

Dr Alison Humphries from Complete Medical Communications provided medical writing support funded by Almirall S.A., Barcelona, Spain. Prior to peer review, Almirall S.A. was offered the opportunity to review this paper for scientific accuracy. Professor Paul Jones is the guarantor for this article, and takes responsibility for the integrity of the work as a whole.

\section{Disclosure}

The author participated in the clinical development of aclidinium as an investigator for the AClidinium CLinical trial Assessing efficacy and safety In Moderate to severe COPD patients (ACCLAIM) COPD I (coordinating investigator), ACCLAIM COPD II (coordinating investigator), and ATTAIN (principal investigator) studies. The author and his institution have received consulting and lecture fees from Almirall S.A. in association with the aclidinium development program, but no fees for the writing of this paper. The author reports no other conflicts of interest in this work.

\section{References}

1. Global Initiative for Chronic Obstructive Lung Disease [webpage on the Internet]. Global strategy for the diagnosis, management and prevention of chronic obstructive pulmonary disease [updated Jan 2014] Available from: http://www.goldcopd.com/guidelines-global-strategyfor-diagnosis-management.html. Accessed November 12, 2014.

2. Global Initiative for Chronic Obstructive Lung Disease [webpage on the Internet]. Global strategy for the diagnosis, management, and prevention of chronic obstructive pulmonary disease [updated 2014]. Available from: http://www.goldcopd.org/uploads/users/files/GOLD_Report2014_ Feb07.pdf. Accessed December 12, 2014. 
3. Karner C, Chong J, Poole P. Tiotropium versus placebo for chronic obstructive pulmonary disease. Cochrane Database Syst Rev. 2014;7: CD009285.

4. Tashkin DP, Celli B, Senn S, et al. A 4-year trial of tiotropium in chronic obstructive pulmonary disease. $N$ Engl $J$ Med. 2008;359(15):1543-1554

5. Singh S, Loke YK, Furberg CD. Inhaled anticholinergics and risk of major adverse cardiovascular events in patients with chronic obstructive pulmonary disease: a systematic review and meta-analysis. JAMA. 2008; 300(12):1439-1450

6. Singh S, Loke YK, Enright PL, Furberg CD. Mortality associated with tiotropium mist inhaler in patients with chronic obstructive pulmonary disease: systematic review and meta-analysis of randomised controlled trials. BMJ. 2011;342:d3215.

7. Jara M, Wentworth $\mathrm{C}$ 3rd, Lanes $\mathrm{S}$. A new user cohort study comparing the safety of long-acting inhaled bronchodilators in COPD. BMJ Open. 2012;2(3): 000841

8. Short PM, Williamson PA, Elder DH, Lipworth SI, Schembri S, Lipworth BJ. The impact of tiotropium on mortality and exacerbations when added to inhaled corticosteroids and long-acting beta-agonist therapy in COPD. Chest. 2012;141(1):81-86.

9. Dong YH, Lin HH, Shau WY, Wu YC, Chang CH, Lai MS. Comparative safety of inhaled medications in patients with chronic obstructive pulmonary disease: systematic review and mixed treatment comparison meta-analysis of randomised controlled trials. Thorax. 2013;68(1): $48-56$.

10. Verhamme KM, Afonso A, Romio S, Stricker BC, Brusselle G, Sturkenboom M. Use of tiotropium Respimat ${ }^{\mathbb{B}}$ SMI vs tiotropium Handihaler ${ }^{\circledR}$ and mortality in patients with COPD. Eur RespirJ. 2013;42(3): 606-615.

11. Wise RA, Anzueto A, Cotton D, et al; TIOSPIR Investigators. Tiotropium Respimat inhaler and the risk of death in COPD. $N$ Engl $J$ Med. 2013;369(16):1491-1501.

12. Ulrik CS. Once-daily glycopyrronium bromide, a long-acting muscarinic antagonist, for chronic obstructive pulmonary disease: a systematic review of clinical benefit. Int J Chron Obstruct Pulmon Dis. 2012;7:673-678.

13. Sechaud R, Renard D, Zhang-Auberson L, de la Motte S, Drollmann A, Kaiser G. Pharmacokinetics of multiple inhaled NVA237 doses in patients with chronic obstructive pulmonary disease (COPD). Int J Clin Pharmacol Ther. 2012;50(2):118-128.

14. Fogarty C, Hattersley H, Di Scala L, Drollmann A. Bronchodilatory effects of NVA237, a once daily long-acting muscarinic antagonist, in COPD patients. Respir Med. 2011;105(3):337-342.

15. Verkindre C, Fukuchi Y, Flémale A, et al. Sustained 24-h efficacy of NVA237, a once-daily long-acting muscarinic antagonist, in COPD patients. Respir Med. 2010;104(10):1482-1489.

16. Vogelmeier C, Verkindre C, Cheung D, et al. Safety and tolerability of NVA237, a once-daily long-acting muscarinic antagonist, in COPD patients. Pulm Pharmacol Ther. 2010;23(5):438-444.

17. D'Urzo A, Ferguson GT, van Noord JA, et al. Efficacy and safety of once-daily NVA237 in patients with moderate-to-severe COPD: the GLOW1 trial. Respir Res. 2011;12:156.

18. Kerwin E, Hébert J, Gallagher N, et al. Efficacy and safety of NVA237 versus placebo and tiotropium in patients with COPD: the GLOW2 study. Eur Respir J. 2012;40(5):1106-1114.

19. Beeh KM, Singh D, Di Scala L, Drollmann A. Once-daily NVA237 improves exercise tolerance from the first dose in patients with COPD: the GLOW3 trial. Int J Chron Obstruct Pulmon Dis. 2012;7:503-513.

20. European Medicines Agency [webpage on the Internet]. Eklira ${ }^{\circledR}$ Genuair ${ }^{\circledR}$ (aclidinium bromide). London, UK: European Medicines Agency; 2014 [updated Dec, 2014]. Available from: http://www.ema.europa. eu/ema/index.jsp?curl=pages/medicines/human/medicines/002211/ human_med_001571.jsp\&mid=WC0b01ac058001d124. Accessed December 1, 2014.
21. US Food and Drug Administration [webpage on the Internet]. Tudorza ${ }^{\circledR}$ Pressair $^{\circledR}$ (aclidinium bromide). Rockville, MD:US Food and Drug Administration; 2012 [updated 2012]. Available from: http://www.accessdata.fda.gov/scripts/cder/drugsatfda/index.cfm?fuseaction=Search.DrugDetails. Accessed December 1, 2014.

22. Gavaldà A, Miralpeix M, Ramos I, et al. Characterization of aclidinium bromide, a novel inhaled muscarinic antagonist, with long duration of action and a favorable pharmacological profile. J Pharmacol Exp Ther. 2009;331(2):740-751.

23. Gavaldà A, Viñals M, Aubets J, Gras J. Effect of formoterol alone and in combination with aclidinium on electrocardiograms in dogs. Eur Respir J. 2012;40(Suppl 56):P2116.

24. Jansat JM, Lamarca R, de Miquel G, Schrödter A, Miletzki B, Gurniak M. Safety and pharmacokinetics of multiple doses of aclidinium bromide, a novel long-acting muscarinic antagonist for the treatment of chronic obstructive pulmonary disease, in healthy participants. J Clin Pharmacol. 2009;49(10):1239-1246.

25. Lasseter KC, Dilzer S, Jansat JM, Garcia Gil E, Caracta C, Ortiz S. Safety and pharmacokinetics of multiple doses of aclidinium bromide administered twice daily in healthy volunteers. Pulm Pharmacol Ther. 2012;25:193-199

26. Lasseter KC, Aubets J, Chuecos F, Garcia Gil E. Aclidinium bromide, a long-acting antimuscarinic, does not affect QT interval in healthy subjects. J Clin Pharmacol. 2010;51(6):923-932.

27. Schmid K, Pascual S, Garcia Gil E, Ortiz S, Jansat JM. Pharmacokinetics and safety of aclidinium bromide, a muscarinic antagonist, in adults with normal or impaired renal function: A phase I, open-label, single-dose clinical trial. Clin Ther. 2010;32(10):1798-1812.

28. de la Motte S, Beier J, Schmid K, Pascual S, Jansat JM, Garcia Gil E. Pharmacokinetics and safety of aclidinium bromide in younger and elderly patients with chronic obstructive pulmonary disease. Int J Clin Pharmacol Ther. 2012;50(6):403-412.

29. Fuhr R, Magnussen H, Sarem K, et al. Efficacy of aclidinium bromide $400 \mu \mathrm{g}$ twice daily compared with placebo and tiotropium in patients with moderate to severe COPD. Chest. 2012;141(3):745-752.

30. Singh D, Magnussen H, Kirsten A, et al. A randomised, placebo- and activecontrolled dose-finding study of aclidinium bromide administered twice a day in COPD patients. Pulm Pharmacol Ther. 2012;25(3):248-253.

31. Kerwin EM, D'Urzo AD, Gelb AF, et al. ACCORD I study investigators. Efficacy and safety of a 12-week treatment with twice-daily aclidinium bromide in COPD patients (ACCORD COPD I). COPD. 2012;9(2): 90-101.

32. Jones PW, Singh D, Bateman ED, et al. Efficacy and safety of twicedaily aclidinium bromide in COPD patients: the ATTAIN study. Eur Respir J. 2012;40(4):830-836.

33. Rennard SI, Scanlon PD, Ferguson GT, et al. ACCORD COPD II: a randomized clinical trial to evaluate the 12-week efficacy and safety of twice-daily aclidinium bromide in chronic obstructive pulmonary disease patients. Clin Drug Investig. 2013;133(12):893-904.

34. Gelb AF, Tashkin DP, Make BJ, Zhong X, Garcia Gil E, Caracta C; LAS-MD-35 study investigators. Long-term safety and efficacy of twicedaily aclidinium bromide in patients with COPD. Respir Med. 2013; 107(12):1957-1965.

35. D’Urzo A, Kerwin E, Rennard S, He T, Garcia Gil E, Caracta C. Oneyear extension study of ACCORD COPD I: safety and efficacy of two doses of twice-daily aclidinium bromide in patients with COPD. COPD. 2013;10(4):500-510.

36. Beier J, Kirsten AM, Mróz R, et al. Efficacy and safety of aclidinium bromide compared with placebo and tiotropium in patients with moderate-to-severe chronic obstructive pulmonary disease: results from a 6-week, randomized, controlled Phase IIIb study. COPD. 2013; 10(4):511-522.

37. Chanez P, Burge PS, Dahl R, et al. Aclidinium bromide provides longacting bronchodilation in patients with COPD. Pulm Pharmacol Ther. 2010;23(1):15-21. 
38. Joos GF, Schelfhout VJ, Pauwels RA, et al. Bronchodilatory effects of aclidinium bromide, a long-acting muscarinic antagonist, in COPD patients. Respir Med. 2010;104(6):865-872.

39. Jones PW, Rennard SI, Agusti A, et al. Efficacy and safety of oncedaily aclidinium in chronic obstructive pulmonary disease. Respir Res. 2011;12:55.

40. Ni H, Soe Z, Moe S. Aclidinium bromide for stable chronic obstructive pulmonary disease. Cochrane Database Syst Rev. 2014;9:CD010509.

41. Donohue JF. Minimal clinically important differences in COPD lung function. COPD. 2005;2(1):111-124.

42. Agusti A, Jones PW, Bateman ED, et al. Improvement in symptoms and rescue medication use with aclidinium bromide in patients with chronic obstructive pulmonary disease: results from ATTAIN. Eur Respir J. 2011;38(Suppl 55):874.

43. Mahler DA, Witek TJ Jr. The MCID of the transition dyspnea index is a total score of one unit. COPD. 2005;2(1):99-103.

44. Jones PW, Quirk FH, Baveystock CM. The St George's Respiratory Questionnaire. Respir Med. 1991;85(Suppl B):25-31.

45. Kerwin E, Jones P, D’Urzo A, Rekeda L, Garcia Gil E, Caracta C. Twice-daily aclidinium bromide in COPD patients: a pooled analysis of lung function in the ACCORD-COPD I and ATTAIN trials. Eur Respir J. 2012;40 (Suppl 56):P2892.

46. Jones PW, Singh D, Kerwin E, Lamarca R, Caracta C, Garcia Gil E. Reduced COPD exacerbations associated with aclidinium bromide versus placebo: a pooled analysis of Phase III data. Thorax. 2012;67 (Suppl 2):A146.
47. Leidy NK, Wilcox TK, Jones PW, Roberts L, Powers JH, Sethi S; EXACT-PRO Study Group. Standardizing measurement of chronic obstructive pulmonary disease exacerbations: reliability and validity of a patient-reported diary. Am J Respir Crit Care Med. 2011;183(3): 323-329.

48. Fuhr R, Magnussen H, Singh D, de Miquel G, Caracta C, Garcia Gil E. Patient assessments of ease of use of Genuair ${ }^{(\mathbb{R}}$ versus Aerolizer $^{\circledR}$ and HandiHaler ${ }^{\mathbb{B}}$. Eur Respir J. 2011;38 (Suppl 55):P3979.

49. van der Palen J, Ginko T, Kroker A, et al. Preference, satisfaction and errors with two dry powder inhalers in patients with COPD. Expert Opin Drug Deliv. 2013;10(8):1023-1031.

50. Donohue J, Rennard S, Celli B, Rekeda L, Garcia Gil E, Caracta C. Safety and tolerability of aclidinium bromide in patients with COPD: pooled results from long-term phase III studies. Chest. 2012;142(4):688A.

51. European Medicines Agency, Committee for Medicinal Products for Human Use (CHMP). Eklira Genuair: CHMP assessment report. May 24, 2012. http://www.ema.europa.eu/docs/en_GB/document_library/ EPAR_-_Public_assessment_report/human/002211/WC500132663. pdf. Accessed February 25, 2015

52. Food and Drug Administration. Tudorza Pressair: Summary review of regulatory action. July 20, 2012. http:/www.accessdata.fda.gov/ drugsatfda_docs/nda/2012/202450Orig1s000SumR.pdf. Accessed February 25, 2015

53. Melani AS, Bonavia M, Cilenti V, et al. Inhaler mishandling remains common in real life and is associated with reduced disease control. Respir Med. 2011;105(6):930-938.
International Journal of COPD

\section{Publish your work in this journal}

The International Journal of COPD is an international, peer-reviewed journal of therapeutics and pharmacology focusing on concise rapid reporting of clinical studies and reviews in COPD. Special focus is given to the pathophysiological processes underlying the disease, intervention programs, patient focused education, and self management protocols.

\section{Dovepress}

This journal is indexed on PubMed Central, MedLine and CAS. The manuscript management system is completely online and includes a very quick and fair peer-review system, which is all easy to use. Visit http://www.dovepress.com/testimonials.php to read real quotes from published authors. 